\section{Effect of Abscisic Acid and Benzyladenine on Fruit Set and Fruit Quality of Apples}

\author{
Duane W. Greene ${ }^{1}$ \\ Department of Plant, Soil and Insect Sciences, University of Massachusetts, \\ Bowditch Hall, Amherst, MA 01003
}

James R. Schupp and H. Edwin Winzeler

Department of Horticulture, Fruit Research and Extension Center, Penn

State University, 290 University Drive, P.O. Box 330, Biglerville, PA

Additional index words. ABA, BA, MaxCel®, fruit thinning, fruit abscission, cropload, Malus $\times$ domestica, agrichemicals, biennial bearing, chemical thinner, flower initiation, cropload

\begin{abstract}
Experiments were conducted over a 5-year period to determine the effects of abscisic acid (ABA) and benzyladenine (BA) applied alone and in combination on fruit set, fruit quality, and return bloom of 'McIntosh' and 'Fuji' apples. ABA thinned in 3 of the 5 years used and it thinned 'McIntosh' when applied at bloom, petal fall, and at the 10-mm fruit size stage. On 'Fuji', ABA thinned over a range of concentrations from 150 to $1000 \mathrm{mg} \cdot \mathrm{L}^{-1}$. It caused leaf yellowing on 'McIntosh' but not on 'Fuji'. When BA was applied with ABA on 'McIntosh', even at a rate as high as $1000 \mathrm{mg} \cdot \mathrm{L}^{-1}$, it either dramatically reduced or prevented leaf yellowing and leaf abscission. The usefulness of applying BA with $A B A$ was inconclusive because of variability in thinning response. ABA advanced surface red color on 'McIntosh' and when combined with $B A$, it reversed the reduction in red color caused by $\mathrm{BA}$.
\end{abstract}

The potential for chemical thinners to aid in consistent cropping of quality apples was recognized as early as the 1940s (Burkholder and McCown, 1941). During the intervening time, many potential thinning compounds were evaluated and several have been effective and consistent enough to be registered for commercial use. Presently, naphthaleneacetic acid (NAA), naphthaleneacetamide, carbaryl, and BA are the compounds most frequently used commercially (Greene, 2002). Each thinning compound has strengths and weaknesses and the use of an individual thinner or thinner combination is often determined by weather, cultivar, geographical location, thinning strength, and consistency of performance (Greene, 2002; Schwailler, 1996). Consequently, with potential limitations that narrow the selection of a thinner, there appears to be a need to have alternative chemical thinners or thinner combinations that can be called on for use under a wide range of geographical, phenological, and environmental situations. There is continuous and ongoing research to discover and develop new thinners (Petracek et al., 2003). Costs of bringing a new thinner to the market may be staggering, attributable in part to rigorous evaluation and the need for extensive toxicological data to assure safety of the compound (Crovetti and Schafer, 1989). Naturally occurring compounds, especially plant hormones, may be registered at

Received for publication 7 Dec. 2010. Accepted for publication 28 Jan. 2011.

${ }^{1}$ To whom reprint requests should be addressed; e-mail dgreene@pssci.umass.edu. considerably lower cost and in less time than synthetic compounds (Rademacher and Bucci, 2002).

ABA is a naturally occurring plant hormone that plays a role in a number of physioabscission-promoting effects in explant systems were instrumental and important in the discovery and characterization of ABA (Addicott, 1983). Subsequent studies have revealed that exogenous application of ABA causes abscission of flowers and young developing fruit of a number of plants, including apple (Edgerton, 1971), cherry (Zucconi et al., 1969), olive (Hartmann et al., 1968), and lupine (Porter and Van Steveninck, 1966). This investigation was undertaken to evaluate the efficacy of ABA as a fruit thinner when used alone and in combination with benzyladenine.

\section{Materials and Methods}

General. All 'McIntosh' trees used in this series of experiments were growing at the University of Massachusetts Horticultural Research Center in Belchertown. Trees were mature and were pruned, sprayed, fertilized, and maintained according to accepted commercial practices.

'Pioneer McIntosh'/M.9-2003. In a block of 'Pioneer McIntosh', 24 uniform trees were selected. At the pink stage of flower development, two limbs per tree were selected, tagged, and measured. All blossom clusters were counted on the tagged portion of each limb and the blossom cluster density then calculated by dividing the number of blossom clusters by the limb cross-sectional area. Trees logical processes (Addicott et al., 1964). Its were organized into six groups (replications) of four trees each based on blossom cluster density. On 4 June, when fruit size averaged $10.9 \mathrm{~mm}$, two trees in each block were sprayed with a dilute handgun application of ABA (Valent Biosciences Corp., Libertyville, IL) at $300 \mathrm{mg} \cdot \mathrm{L}^{-1}$ with $0.05 \%$ Regulaid surfactant (Kalo Inc., Overland Park., KS). ABA was first dissolved in ethanol to provide a $10 \%(\mathrm{w} /$ v) stock solution. This stock solution was then placed in the spray tank to give a final ethanol concentration of $0.005 \%(\mathrm{v} / \mathrm{v})$. One tree in each block was similarly sprayed with benzyladenine at $75 \mathrm{mg} \cdot \mathrm{L}^{-1}$ as a dilute handgun application as well as one tree in each block that previously received a spray of ABA. A fourth tree in each block was left unsprayed and served as the untreated control. At the end of "June drop" in July, all fruit on the tagged portion of each limb were counted and recorded.

At the normal time on 15 Sept., 30 fruit were randomly harvested from each tree. All fruit were weighed. Red color was estimated visually to the nearest $10 \%$ on all harvested fruit. In addition, it was noted if the fruit had sufficient intensity of red color to qualify as a U.S. Extra Fancy Fruit. Ten representative fruit per tree were selected from the harvested fruit for further analysis. Flesh firmness was determined using an Efegi penetrometer (McCormick Fruit Co., Yakima, WA) equipped with an 11-mm head by taking two readings from each fruit at the interface between green and red portions of the fruit. Juice was collected during the determination of the flesh firmness and soluble solids determined on the composite sample using a handheld refractometer (Fisher Scientific, Waltham, MA). Fruit were cut in half, dipped in an iodine solution, and then the intensity and pattern of residual starch determined using the Cornell generic starch chart (Blanpied and Silsby, 1992). At the pink stage of flower development in 2004, the number of blossom clusters was counted on the limbs tagged in 2003 and the blossom cluster density calculated to quantify the extent of return bloom.

'Pioneer McIntosh'/M.9-2004. The experiment and the experimental procedure described for 2003 were repeated in 2004 on different trees in the same block. The following modifications were made in 2004. Replications were increased to eight. Only the tagged limbs on the trees designated to receive $\mathrm{ABA}$ were sprayed. On trees designated to receive both $\mathrm{ABA}$ and $\mathrm{BA}, 75 \mathrm{mg} \cdot \mathrm{L}^{-1} \mathrm{BA}$ (MaxCel; Valent Biosciences Corp.) was applied as a dilute application to the whole tree and then after the spray had dried, ABA was applied as a dilute spray only to the tagged limbs. Application was made on 21 May when fruit size averaged $9.1 \mathrm{~mm}$. A 25-apple sample was harvested on 14 Sept. from each tree.

'Marshall McIntosh'/M.26-2005. In a block of mature 'Marshall McIntosh'/M.26, 96 trees were selected. At the pink stage of flower development, two limbs per tree with a diameter between 10 and $15 \mathrm{~cm}$ were selected, tagged, and measured. The total number of spur blossom clusters was counted and the blossom 
cluster density calculated. Trees were organized into eight groups (replications) of 12 trees each based on blossom cluster density. The ABA solution was prepared as previously described and Regulaid surfactant at $0.05 \%$ was included in all ABA sprays. ABA was applied at three different times: bloom on 12 May, petal fall on 20 May, and the 10-mm stage on 2 June. At each timing, two trees in each replication were sprayed using a commercial airblast sprayer at a tree row volume dilute of $1173 \mathrm{~L} \cdot \mathrm{ha}^{-1}$. On 2 June, BA at 100 $\mathrm{mg} \cdot \mathrm{L}^{-1}$ was applied with the airblast sprayer to three trees in each replication that were previously unsprayed and to one tree that had received $\mathrm{ABA}$ at each of the three specified times of application. Three trees in each replication were left unsprayed and served as the controls for the three times of ABA application. After each ABA application, trees were monitored visually at 2-d intervals to record symptoms of ABA or ABA and BA. At normal harvest time on 12 and 13 Sept., fruit were harvested from each tree. As a result of the large number of samples, Replications 1 to 4 were harvested and processed on $12 \mathrm{Sept}$. and Replications 5 to 8 were similarly harvested and processed on 13 Sept. At each harvest date, a 30-apple sample was randomly harvested from the periphery of each tree. Fruit evaluation was similar to that described for the experiment done on 'Pioneer McIntosh' in 2003.

'Autumn Rose Fuji'/M.9-2008 and 2009. A block of mature 'Autumn Rose Fuji' growing at the Penn State Fruit Research and Extension Center, Biglererville, PA, was selected. A factorial experiment was established with two rates of $\mathrm{BA}$ and five rates of $\mathrm{ABA}$ with five replications. Treatments were applied on 14 May 2008 and on 13 May 2009. BA was applied at a rate of $150 \mathrm{mg} \cdot \mathrm{L}^{-1}$ to 10-tree plots using an airblast sprayer that was calibrated to apply $935 \mathrm{~L} \cdot \mathrm{ha}^{-1}$. ABA was applied a rates of $0,50,150,300$, and 1000 $\mathrm{mg} \cdot \mathrm{L}^{-1}$ to individual trees to the point of drip using a $\mathrm{CO}_{2}$ pressure sprayer (Bellspray, Inc., Opelousas, LA) calibrated to deliver spray at $276 \mathrm{KPa}$ and fitted with a Teejet 8004 flat fan nozzle (Spraying Systems Inc., Wheaton, IL).

Before spray application, two branches per tree were selected and tagged. The number of flower clusters was counted and at the end of "June drop," persisting fruit were counted. Bloom density was expressed as the number of flower clusters per unit of limb cross-sectional area (LCSA) and final fruit set as either a percent fruit of the original number of blossom clusters or as the number per LCSA. In 2008 , the number of flower clusters arising on 1 -year-old wood and the number of flowers clusters arising from spurs or terminal buds on 1-year-old wood were counted separately and fruit set was calculated for each category of flower cluster. At normal commercial harvest time, all fruit were harvested from individual trees and weighed. A 20-apple random sample was collected for further quality and maturity assessment. Fruit weight and fruit diameter and length were measured. Fruit were cut at the equator, dipped in iodine solution, and then the starch pattern and intensity were visually estimated on a scale from 1 to 8 using the Cornell starch chart (Blanpied and Silsby, 1992). Return bloom was determined in trees treated in 2008 by counting the number of blossom clusters at the pink stage of flower development and calculating the number of flower clusters per LCSA.

Statistical analysis. Statistical analysis was done using a two-way analysis of variance (ANOVA) for main effects and interaction effects followed by multiple mean comparisons using Duncan's new multiple range test applied when significant differences were found with the ANOVA. Each BA treatment subpopulation was analyzed separately because of significant $\mathrm{BA} \times \mathrm{ABA}$ interactions in the 2008 data. Orthogonal paired comparisons were analyzed to give indications of whether varying levels of ABA resulted in varying effects of thinning within each $\mathrm{BA}$ subpopulation.

\section{Results}

'Pioneer McIntosh'-2003. Application of $\mathrm{ABA}$ at $300 \mathrm{mg} \cdot \mathrm{L}^{-1}$ resulted in no reduction in cropload, whereas BA at the same 10-mm time of application did cause thinning (Table 1). When ABA and BA were combined, there was a significant interaction for fruit per centimeter LCSA, which resulted in a reduction in the amount of thinning induced by BA. This interaction was not strong because it was significant at $P=0.05$ and nonsignificant when expressed as percent set. BA increased return bloom, ABA had no influence, and return bloom was intermediate between that caused by individual applications when both were applied in combination. The interaction between ABA and BA was highly significant for return bloom.

At harvest, the weight of fruit from trees sprayed with ABA, BA, and the combination was larger than fruit harvested from untreated control trees (Table 2). The percent of the surface of fruit with red color was reduced by $\mathrm{BA}$ and the combination spray of BA and ABA. Extra Fancy Fruit grade requires at least $50 \%$ skin coverage of red color for the McIntosh cultivar. Although ABA did not significantly increase red color rating, it did increase the percent of the fruit that were judged to be in the Extra Fancy category. BA reduced the percent fruit in the U.S. Extra Fancy category. No treatment affected flesh firmness. Fruit treated with BA increased soluble solids concentration (SSC), ABA alone had no effect, and the combination spray was intermediate. BA reduced starch rating, indicating that ripening was delayed.

'Pioneer McIntosh'-2004. Application of $\mathrm{ABA}, \mathrm{BA}$, and the combination of $\mathrm{ABA}$ plus BA resulted in significant thinning when expressed either as fruit per centimeter LCSA or as percent set (Table 1). The interaction between $\mathrm{ABA}$ and $\mathrm{BA}$ for fruit abscission was significant. ABA, BA, and the combination of $\mathrm{ABA}$ plus $\mathrm{BA}$ increased return bloom.

Only BA increased mean fruit weight. Fruit weight from trees treated with $\mathrm{ABA}$ alone was similar to the fruit weight from untreated control trees. Fruit weight from trees treated with both ABA and BA was similar in weight to those sprayed with $\mathrm{BA}$ alone (Table 2). ABA increased red color and BA reduced both red color and the percent fruit classified as U.S. Extra Fancy. There were no treatment effects on flesh firmness. BA increased SSC and ABA reduced starch rating.

'Marshall McIntosh'-2005. Application of both $\mathrm{ABA}$ and $\mathrm{BA}$ resulted in significant thinning (Table 3 ). The $\mathrm{ABA} \times$ time of application interaction was significant, indicating greater thinning when ABA was applied at the $10-\mathrm{mm}$ stage of fruit development. In 2006 , return bloom was separated into bloom

Table 1. Effect of abscisic acid (ABA) and benzyladenine (BA) on fruit set and return bloom of 'Pioneer McIntosh'.

\begin{tabular}{|c|c|c|c|c|}
\hline $\begin{array}{l}\text { Treatment }^{2} \\
\left(\mathrm{mg} \cdot \mathrm{L}^{-1}\right)\end{array}$ & $\begin{array}{c}\text { Blossom } \\
\text { cluster/cm limb } \\
\text { cross-sectional area }\end{array}$ & $\begin{array}{c}\text { Fruit } / \mathrm{cm} \\
\text { limb } \\
\text { cross-sectional area }\end{array}$ & $\begin{array}{c}\text { Fruit } \\
\text { set }(\%)\end{array}$ & $\begin{array}{c}\text { Return bloom } \\
\text { Blossom cluster/cm } \\
\text { cross-sectional area }\end{array}$ \\
\hline Control & $11.5^{y}$ & 11.5 & 105 & 3.8 \\
\hline ABA 300 & 11.7 & 8.0 & 77 & 3.2 \\
\hline BA 75 & 11.5 & 3.6 & 35 & 11.9 \\
\hline $\mathrm{ABA}+\mathrm{BA}$ & 11.5 & 6.3 & 60 & 7.8 \\
\hline \multicolumn{5}{|l|}{ Significance } \\
\hline $\mathrm{ABA}$ & NS & NS & NS & NS \\
\hline $\mathrm{BA}$ & NS & * & * & * \\
\hline $\mathrm{ABA} \times \mathrm{BA}$ & NS & $*$ & NS & $* * *$ \\
\hline Control & 11.1 & 13.0 & 104 & 6.4 \\
\hline ABA 300 & 11.0 & 2.3 & 25 & 8.2 \\
\hline BA 75 & 11.4 & 7.5 & 76 & 12.0 \\
\hline $\mathrm{ABA}+\mathrm{BA}$ & 11.1 & 1.7 & 16 & 14.3 \\
\hline \multicolumn{5}{|l|}{ Significance } \\
\hline $\mathrm{ABA}$ & NS & $* * *$ & $* * *$ & * \\
\hline $\mathrm{BA}$ & NS & $* * *$ & $* * *$ & $* *$ \\
\hline $\mathrm{ABA} \times \mathrm{BA}$ & NS & * & ** & NS \\
\hline
\end{tabular}

${ }^{\mathrm{z}} \mathrm{ABA}$ and BA applications were made on 4 June 2003 when mean fruit size averaged $10.9 \mathrm{~mm}$ and 21 May 2004 when mean fruit size averaged $9.1 \mathrm{~mm}$. ABA and BA were applied separately as dilute hand-gun applications. Regulaid at $0.05 \%$ was included with the ABA.

$\mathrm{y}_{\mathrm{NS}}, *, * * * * *$ Non-significant or significant at $P=0.05,0.01$, or 0.001 , respectively. 
on shoots that grew on 1-year-old wood and on spur bloom. BA increased return bloom on spur bloom, lateral bloom, and the combinainfluence return bloom.

Both $\mathrm{ABA}$ and $\mathrm{BA}$ increased fruit weight and there was an $\mathrm{ABA} \times$ time of $\mathrm{ABA}$ application interaction (Table 4). This interaction was the result of ABA increasing fruit weight more when applied at the $10-\mathrm{mm}$ stage of fruit development. ABA did not affect the percent of the fruit surface with red color but it did reduce the intensity of color and the percent fruit classified as U.S. Extra Fancy. $\mathrm{BA}$ reduced both the percent red color and the fruit classified as U.S. Extra Fancy. BA tion of spur plus lateral bloom. ABA did not

increased the fruit flesh firmness, SSC, and starch rating, whereas ABA did not.

'Autumn Rose Fuji'/M.9-2008. Regardless of the method used to quantify fruit set, $\mathrm{BA}$ and $\mathrm{ABA}$ reduced final fruit set and the thinning interaction between the two was significant (Table 5). In the absence of BA, the thinning response to $\mathrm{ABA}$ appears to be linear. When ABA and BA were applied to the same tree, ABA caused additional thinning only at the highest ABA rate. The influence of ABA and BA on fruit size, including fruit weight, diameter, and length, was highly significant and the interaction between ABA and BA was significant at $P=0.01$ for all of these parameters (Table 6). The nature of the

Table 2. Effect of abscisic acid (ABA) and benzyladenine (BA) on fruit weight and fruit quality of 'Pioneer McIntosh'

\begin{tabular}{|c|c|c|c|c|c|c|}
\hline $\begin{array}{l}\text { Treatment } \\
\left(\mathrm{mg} \cdot \mathrm{L}^{-1}\right)\end{array}$ & $\begin{array}{l}\text { Fruit wt } \\
\text { (g) }\end{array}$ & $\begin{array}{l}\text { Red color } \\
(\%)\end{array}$ & $\begin{array}{l}\text { U.S. Extra } \\
\text { fancy }(\%)\end{array}$ & $\begin{array}{l}\text { Flesh firmness } \\
\text { (N) }\end{array}$ & $\begin{array}{c}\text { Soluble solids } \\
(\%)\end{array}$ & $\begin{array}{c}\text { Starch rating } \\
(1-8)\end{array}$ \\
\hline Control & $133^{y}$ & 67 & 75 & 70.2 & 11.1 & 6.3 \\
\hline ABA 300 & 146 & 72 & 88 & 70.2 & 11.1 & 6.2 \\
\hline BA 75 & 170 & 62 & 52 & 72.0 & 11.9 & 5.7 \\
\hline $\mathrm{ABA}+\mathrm{BA}$ & 163 & 65 & 68 & 70.2 & 11.3 & 5.7 \\
\hline \multicolumn{7}{|l|}{ Significance } \\
\hline $\mathrm{ABA}$ & * & NS & $* *$ & NS & NS & NS \\
\hline BA & $* *$ & ** & * & NS & $*$ & * \\
\hline $\mathrm{ABA} \times \mathrm{BA}$ & NS & $*$ & NS & NS & $*$ & NS \\
\hline Control & 139 & 66 & 77 & 68.5 & 11.1 & 6.5 \\
\hline ABA 300 & 146 & 72 & 76 & 70.7 & 11.5 & 6.0 \\
\hline BA 75 & 190 & 63 & 51 & 70.2 & 12.0 & 6.2 \\
\hline $\mathrm{ABA}+\mathrm{BA}$ & 197 & 65 & 40 & 69.4 & 11.9 & 5.7 \\
\hline \multicolumn{7}{|l|}{ Significance } \\
\hline $\mathrm{ABA}$ & NS & * & NS & NS & NS & $*$ \\
\hline BA & $* * *$ & * & $* *$ & NS & $*$ & NS \\
\hline $\mathrm{ABA} \times \mathrm{BA}$ & NS & NS & NS & NS & NS & NS \\
\hline
\end{tabular}

${ }^{\mathrm{z}} \mathrm{ABA}$ applications containing $0.05 \%$ Regulaid were made on 12 May (bloom), 20 May (petal fall), and 2 June $(10 \mathrm{~mm})$ using a commercial air-blast sprayer at a tree row volume (TRV) dilute rate of $1169 \mathrm{~L} \cdot \mathrm{ha}^{-1}$. BA was similarly applied on 2 June at the TRV dilute rate of $1169 \mathrm{~L} \cdot \mathrm{ha}^{-1}$.

${ }_{\mathrm{NS}}, *, * *, * *$ Non-significant or significant at $P=0.05,0.01$, or 0.001 , respectively. interaction was similar for each. When $\mathrm{ABA}$ was applied alone, there appeared to be a linear increase in weight, diameter, and length with increasing ABA concentration. When ABA was applied to trees that previously received BA, ABA had no influence. BA increased the fruit length/diameter ratio, whereas ABA had no influence. Both ABA and BA increased return bloom but $\mathrm{BA}$ was more effective. The response to ABA appeared to be linear with greater return bloom being associated with higher rates and greater thinning.

The experiment on 'Autumn Rose Fuji' was repeated on different trees in the same block in 2009. ABA did not thin and the response to BA was small but statistically significant (Table 6). No return bloom was taken in 2010 because of the minimal thinning response in 2009.

\section{Discussion}

The mode of action for ABA thinning in apples is unknown. ABA influences many physiological events in the plant (Addicott and Lyon, 1969) and several of these individually or in some combination may be responsible for thinning. The 8 - to $15-\mathrm{mm}$ fruit size is the stage when developing fruit are easily thinned because carbohydrate demand by developing fruit and other sinks often exceeds the supply provided by photosynthesis (Lakso et al., 2006). Byers et al. (1990a, 1990b) showed that fruit could be thinned by shading trees or by applying photosynthetic inhibitors, both of which reduce the carbohydrate available to the competing sinks. Yuan and Huang (1988) observed extensive drop in litchi when young fruit were shaded and they correlated high levels of ABA in the fruit with this heavy drop. Gomez-Cadenas et al. (2000) attributed fruitlet abscission in Satusma mandarin orange

Table 3. Effect of $1000 \mathrm{mg} \cdot \mathrm{L}^{-1}$ abscisic acid (ABA), time of ABA application, $100 \mathrm{mg} \cdot \mathrm{L}^{-1}$ benzyladenine (BA), and combinations on fruit set and return bloom of 'McIntosh' apples, 2005.

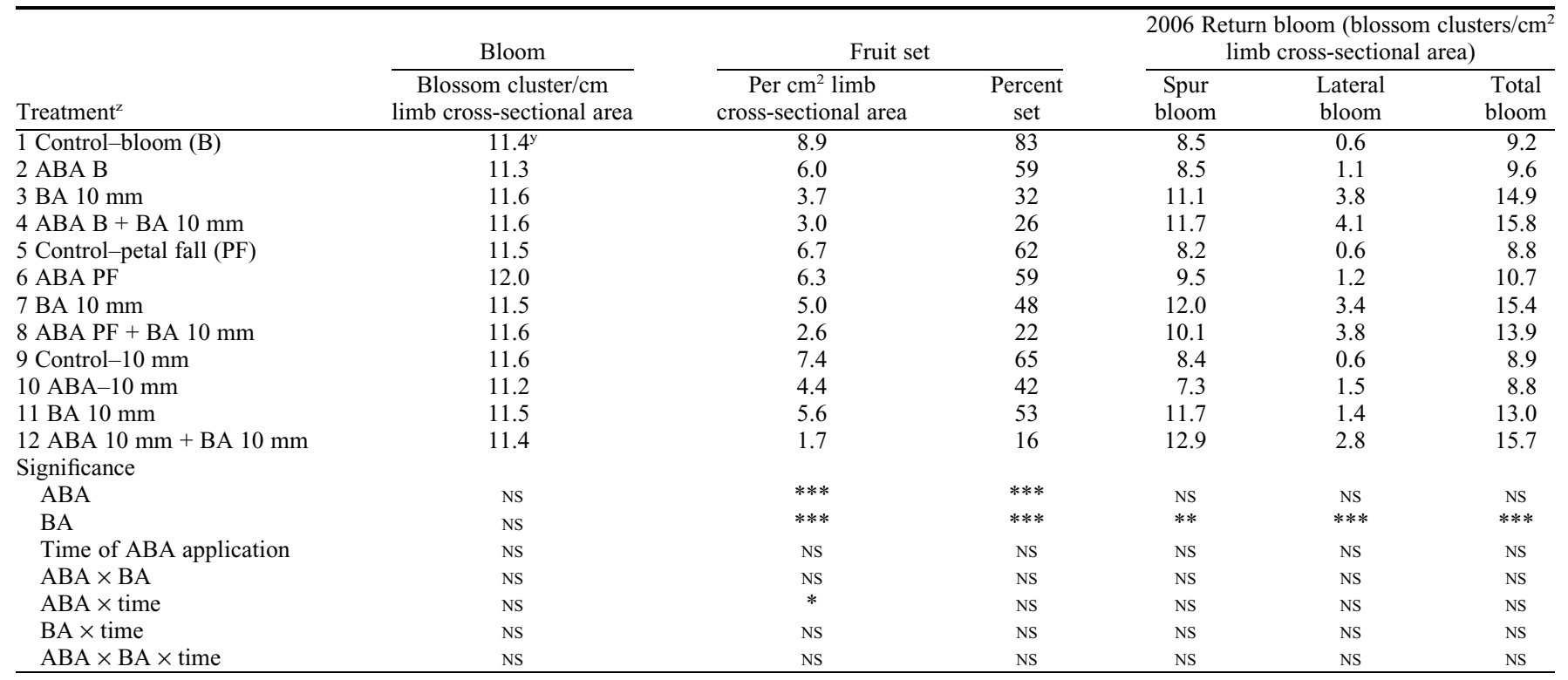

${ }^{\mathrm{z}} \mathrm{ABA}$ applications containing $0.05 \%$ Regulaid were made on 12 May (bloom), 20 May (petal fall), and 2 June (10 mm) using a commercial air-blast sprayer at a tree row volume (TRV) dilute rate of $125 \mathrm{gal} / \mathrm{acre}$. BA was similarly applied on 2 June at the TRV dilute rate of $1169 \mathrm{~L} \cdot \mathrm{ha} \mathrm{a}^{-1}$.

${ }_{\mathrm{NS}}, *, * *, * *$ Non-significant or significant at $P=0.05,0.01$, or 0.001 , respectively. 
Table 4. Effect of $1000 \mathrm{mg} \cdot \mathrm{L}^{-1}$ abscisic acid (ABA), time of ABA application, $100 \mathrm{mg} \cdot \mathrm{L}^{-1}$ benzyladenine (BA), and combinations on fruit quality parameters at harvest, 2005.

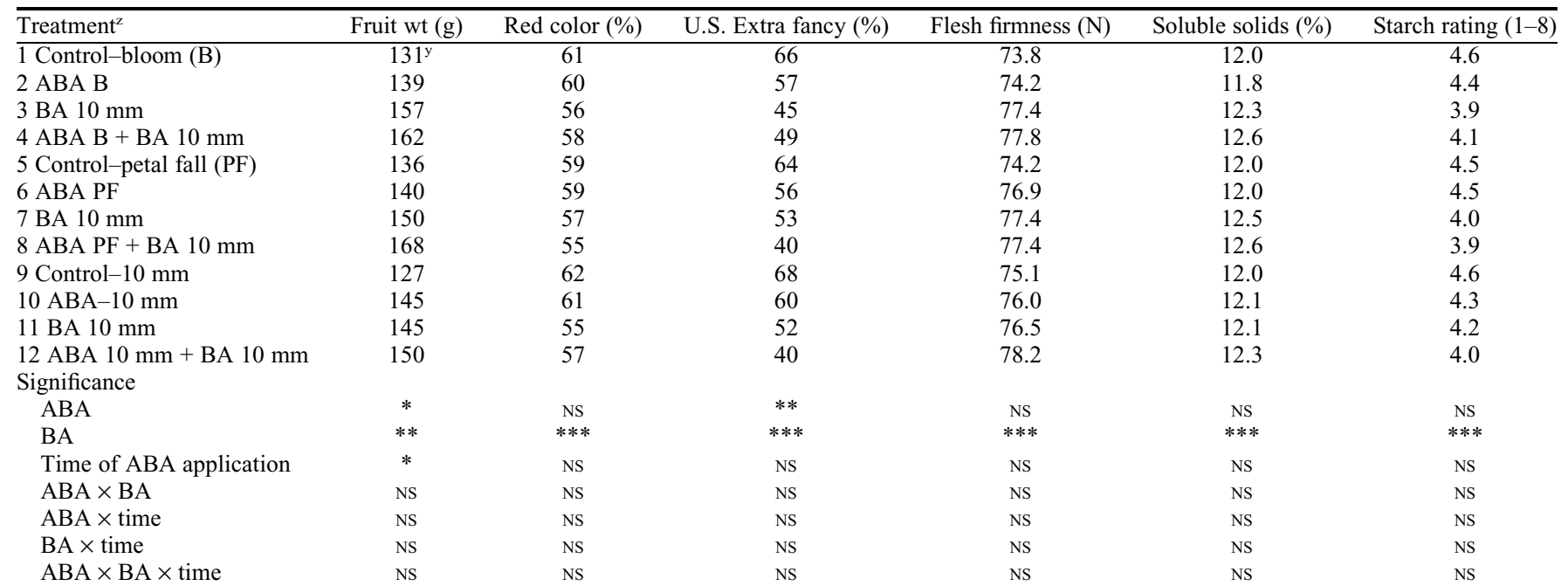

${ }^{\mathrm{z}} \mathrm{ABA}$ applications containing $0.05 \%$ Regulaid were made on 12 May (bloom), 20 May (petal fall), and 2 June (10 mm) using a commercial air-blast sprayer at a tree row volume (TRV) dilute rate of $1169 \mathrm{~L} \cdot \mathrm{ha}^{-1}$. BA was similarly applied on 2 June at the TRV dilute rate of $1169 \mathrm{~L} \cdot \mathrm{ha}^{-1}$.

${ }_{\mathrm{NS}}, *, * * * * *$ Non-significant or significant at $P=0.05,0.01$, or 0.001 , respectively.

Table 5. Effect of abscisic acid (ABA) and benzyladenine (BA) on fruit set and return bloom of 'Autumn Rose Fuji', Pennsylvania.

\begin{tabular}{|c|c|c|c|c|c|c|}
\hline \multicolumn{2}{|c|}{ Treatment $^{\mathrm{z}}\left(\mathrm{mg} \cdot \mathrm{L}^{-1}\right)$} & $\begin{array}{c}\text { Fruit/cm limb } \\
\text { cross-sectional area }\end{array}$ & Fruit/spur (no.) & $\begin{array}{c}\text { Return bloom } \\
\begin{array}{c}\text { Blossom clusters } / \mathrm{cm} \mathrm{limb} \\
\text { cross-sectional area }\end{array}\end{array}$ & $\begin{array}{c}\text { Fruit/cm limb } \\
\text { cross-sectional area }\end{array}$ & Fruit/spur (no.) \\
\hline & & -------- & ---- 2008 Expt. & ------------------------ & -------- 2009 & - \\
\hline 0 & 50 & $53 \mathrm{a}$ & $0.46 \mathrm{ab}$ & 3.7 & 19.1 & 2.1 \\
\hline 0 & 150 & $39 \mathrm{ab}$ & $0.37 \mathrm{bc}$ & 5.1 & 15.4 & 1.8 \\
\hline 0 & 300 & $25 \mathrm{~b}$ & $0.24 \mathrm{c}$ & 7.0 & 19.6 & 2.0 \\
\hline 0 & 1000 & $6 \mathrm{c}$ & $0.08 \mathrm{~d}$ & 7.0 & 13.7 & 1.8 \\
\hline 150 & 150 & $27 \mathrm{a}$ & $0.31 \mathrm{a}$ & 6.4 & 14.6 & 1.6 \\
\hline 150 & 300 & $26 \mathrm{a}$ & $0.27 \mathrm{a}$ & 9.0 & 12.5 & 1.3 \\
\hline 150 & 1000 & $7 \mathrm{~b}$ & $0.05 \mathrm{~b}$ & 7.8 & 11.4 & 1.2 \\
\hline \multicolumn{7}{|c|}{ Significance } \\
\hline No $\mathrm{E}$ & & $37 \mathrm{a}$ & $0.35 \mathrm{a}$ & $5.1 \mathrm{~b}$ & 16.7 & $1.9 \mathrm{a}$ \\
\hline BA & & $23 \mathrm{~b}$ & $0.22 \mathrm{~b}$ & $8.7 \mathrm{a}$ & 13.1 & $1.4 \mathrm{~b}$ \\
\hline
\end{tabular}

${ }^{\mathrm{z}} \mathrm{ABA}$ and BA applied 13 and 14 May in 2008 and 2009, respectively.

'Mean separation within no BA and BA by Duncan's new multiple range test, $P=0.05$.

${ }^{\mathrm{x}} \mathrm{NS}, *, * *, * * *$ Non-significant or significant at $P=0.05,0.01$, or 0.001 , respectively.

to carbon shortage in the tree that is regulated in part by ABA. ABA plays a central role in stomatal closing, thus restricting gas exchange and photosynthesis (Beardsell and Cohen, 1975). Reduced phtotosynthesis as a result of stomatal closure would reduce the amount of photosynthate produced by the plant. Therefore, ABA could have a profound effect on the carbohydrate balance and that which is available for rapidly growing fruit at a developmental stage where there is a fine balance between supply and demand.

Ethylene is one of the hormones positively linked to leaf and fruit abscission (Osbourne, 1989) and it is known that ABA increases ethylene production in many plants including apple. Edgerton (1971) applied a foliar spray of ABA to spurs of 'Early McIntosh' apples and noted a rapid increase in ethylene production from exposed spurs followed by a rapid stimulation of fruit drop. NAA also increases ethylene production and this has also been proposed as a possible mechanism of thinning action by NAA (Walsh et al., 1979).

ABA application advances senescence in many plants and plant parts. Changes in hormonal balance by a reduction in the growth promoters gibberellic acid, cytokinins, and auxins and the elevation of ethylene production characteristic of senescence may be a broader contributing factor that may lead to senescence (Blanchard et al., 2007). ABA increases the production of cellulase in both cotton and bean (Craker and Abeles, 1969).

$\mathrm{ABA}$ is known to promote and accelerate leaf senescence (Goldthwaite, 1988; Nooden, 1988 ) and yellowing is a common symptom of senescence (Addicott and Lyon, 1969). Leaf yellowing has been reported in several plants, including Arabidopsis (Zacarias and Reid, 1990), pansy (Waterland et al., 2010), and geranium (Mutui et al., 2005). In this investigation, ABA caused leaf yellowing and chlorosis on 'McIntosh' in all 3 years and this response appeared to be rate-dependent and quite severe at high rates. When ABA was applied to 'Fuji', no leaf yellowing was noted in either year and the rates used were as high as those used on 'McIntosh'. When ABA was applied on 'Delicious' at comparable rates, leaf yellowing was noted but the yellowing was not as extensive as on 'McIntosh' (D. Greene, unpublished data). Gent and McAvoy (2000) confirmed that plant responses to hormones are highly variable and suggested that they need to be examined in different species, 
Table 6. Effect of abscisic acid (ABA) and benzyladenine (BA) on fruit weight, fruit length and diameter, and length/diameter ratio of 'Autumn Rose Fuji', Pennsylvania.

\begin{tabular}{|c|c|c|c|c|c|}
\hline \multicolumn{2}{|c|}{ Treatment $^{\mathrm{z}}\left(\mathrm{mg} \cdot \mathrm{L}^{-1}\right)$} & \multirow{2}{*}{$\begin{array}{l}\text { Fruit wt } \\
\text { (g) }\end{array}$} & \multirow{2}{*}{$\begin{array}{l}\text { Fruit length } \\
\quad(\mathrm{cm})\end{array}$} & \multirow{2}{*}{$\begin{array}{l}\text { Fruit diam } \\
\quad(\mathrm{cm})\end{array}$} & \multirow{2}{*}{$\begin{array}{c}\text { Length/diameter } \\
\text { ratio }\end{array}$} \\
\hline$\overline{\mathrm{BA}}$ & $\overline{\mathrm{ABA}}$ & & & & \\
\hline 0 & 0 & $206 b^{y, x}$ & $6.6 \mathrm{c}$ & $7.7 \mathrm{c}$ & $0.85 \mathrm{~b}$ \\
\hline 0 & 50 & $255 \mathrm{~b}$ & $7.2 \mathrm{~b}$ & $8.3 \mathrm{~b}$ & $0.87 \mathrm{ab}$ \\
\hline 0 & 150 & $270 \mathrm{ab}$ & $7.5 \mathrm{ab}$ & $8.4 \mathrm{ab}$ & $0.88 \mathrm{a}$ \\
\hline 0 & 300 & $265 \mathrm{ab}$ & $7.3 \mathrm{ab}$ & $8.5 \mathrm{ab}$ & $0.86 \mathrm{ab}$ \\
\hline 0 & 1000 & $293 a$ & $7.7 \mathrm{a}$ & $8.7 \mathrm{a}$ & $0.88 \mathrm{a}$ \\
\hline 150 & 0 & 283 & 7.5 & 8.6 & 0.88 \\
\hline 150 & 50 & 285 & 7.6 & 8.6 & 0.89 \\
\hline 150 & 150 & 304 & 7.8 & 8.8 & 0.88 \\
\hline 150 & 300 & 277 & 7.5 & 8.5 & 0.89 \\
\hline 150 & 1000 & 285 & 7.6 & 8.6 & 0.88 \\
\hline \multicolumn{6}{|c|}{ Significance } \\
\hline & & $258 \mathrm{~b}$ & $7.3 \mathrm{~b}$ & $8.3 \mathrm{~b}$ & 0.87 \\
\hline $\mathrm{B}$ & & $287 \mathrm{a}$ & $7.6 \mathrm{a}$ & $8.6 \mathrm{a}$ & 0.88 \\
\hline $\mathrm{B}$ & & $* * *$ & $* * *$ & $* * *$ & $* *$ \\
\hline $\mathrm{Al}$ & & $* * *$ & $* * *$ & $* * *$ & NS \\
\hline B & & $*$ & $* *$ & $* *$ & NS \\
\hline
\end{tabular}

${ }^{\mathrm{z}} \mathrm{ABA}$ and BA applied 13 and 14 May in 2008 and 2009, respectively.

${ }^{y}$ Mean separation within no BA and BA by Duncan's new multiple range test $(P=0.05)$.

${ }_{\mathrm{x}}^{\mathrm{NS}, *}, * *, * * *$ Non-significant or significant at $P=0.05,0.01$, or 0.001 , respectively.

cultivars, and developmental stages. Leaf yellowing in apple appears to be cultivardependent.

Although not quantified in this investigation, the leaf yellowing on 'McIntosh' was judged to be severe enough to be a deterrent for use as a thinner alone on this cultivar. When ABA was applied either as a tank mix with $\mathrm{BA}$ or on trees that previously received BA, ABA leaf yellowing was significantly reduced or eliminated, even when high rates of ABA were used. It is well documented that cytokinins can defer senescence and reduce yellowing in leaves (Gan and Amasino, 1995; Van Staden et al., 1988); thus, it is not surprising that BA was able to prevent yellowing in leaves that were treated with ABA. A patent has been applied for to use BA to counteract ABA-induced yellowing in leaves without impacting transpiration reduction (Liu et al., 2010). In cultivars that are susceptible to ABA-induced leaf yellowing, it may be necessary to include BA as a companion thinner.

A major reason to thin apples is to assure return bloom. All thinners have the potential to enhance return bloom by causing abscission of young developing fruit, which are a primary source of flower bud inhibition. Some thinners, including NAA (Harley et al., 1958) and ethephon (Byers, 2003), may increase return bloom beyond that can be expected from just a simple reduction in cropload. It is clear from this investigation that $\mathrm{ABA}$ does not, by itself, enhance return bloom and there are indications that it may not enhance return bloom even when it thins (Table 3).

An important attribute of a thinner is consistency of response (Wertheim, 2000). In this investigation, ABA thinned 'McIntosh' in 2 of 3 years and 'Fuji' in 1 of 2 years. This confirms an earlier report by Edgerton (1971) that ABA thinned several cultivars of apples in 2 different years. The response to thinners is modified by many factors, including thinner rate and time, tree condition, and environmental factors (Williams and Edgerton, 1981). Warm temperature after application is an important factor that determines the extent of thinning (Greene, 2002). Cloudy weather accompanied by warm temperatures further accentuates the thinner response (Lehman et al., 1987; McArtney et al., 2004). In this investigation, ABA thinned in 2 of 3 years on 'McIntosh'. In 2003 and 2004, identical experiments were done on similar trees. ABA thinned in 2004 but not in 2003, although the temperature the $5 \mathrm{~d}$ after application was virtually identical. In 2005, ABA thinned when applications were made at bloom, petal fall, or the $10-\mathrm{mm}$ stage and temperatures ranged from 12 to $29.5^{\circ} \mathrm{C}$. Similar temperatures followed application of ABA to 'Fuji' in Pennsylvania in both 2008 and 2009 but thinning occurred only in 2008. It appears that factor(s) other than temperature after application may be important to thinner response after ABA application.

$\mathrm{BA}$ is a relatively new chemical thinner. It is characterized as being a mild thinner when used alone and somewhat more potent when applied with carbaryl (Greene, 1993). The future of carbaryl is in question because it can no longer be used as a thinner on apples in a number of European countries. Therefore, there is a need to identify a thinner that can be used in conjunction with BA to provide a thinning combination that can be reliably used when more aggressive thinning is required. In 2003, ABA did not thin but BA did. When used in combination, the thinning of BA was reduced by $\mathrm{ABA}$ and the interaction was significant. In 2004, both BA and ABA thinned and when used in combination, there was a synergistic response and the interaction was significant. In 2005, both $\mathrm{BA}$ and $\mathrm{ABA}$ thinned and the response was additive regardless of the time of application. In 'Fuji' in 2008, BA and ABA thinned individually but when combined, ABA provided little or no additional thinning. Clearly, additional work will be required to more completely define the relationship between $\mathrm{ABA}$ and $\mathrm{BA}$ when used in combination as a thinner.

\section{Literature Cited}

Addicott, F.T. 1983. Abscisic acid in abscission, p. 269-300. In: Addicott, F.T. (ed.). Abscisic acid. Praeger Publishers, New York, NY.

Addicott, F.T., H.R. Carns, J.L. Lyon, O.E. Smith, and J.L. McMeans. 1964. On the physiology of abscission, p. 687-703. In: Nitsch, J.P. Regulaateurs de la Croissance vegetale. CNRS, Paris, France.

Addicott, F.T. and J.L. Lyon. 1969. Physiology of abscisic acid and related substances, p. 139164. In: Machlis, L., W. Briggs, and R.B. Park. (eds.). Ann rev. plant physiology. Vol. 20. Annual Reviews Inc., Palo Alto, CA.

Beardsell, M.F. and D. Cohen. 1975. Relationship between leaf water status, abscisic acid levels, and stomatal resistance in maize and sorghum. Plant Physiol. 56:207-212.

Blanchard, M.G., L.A. Newton, E.S. Runkle, D. Woolard, and C.A. Campbell. 2007. Exogenous application of abscisic acid improved the postharvest drought tolerance of several annual bedding plants. Acta Hort. 755:127132.

Blanpied, G.D. and K.J. Silsby. 1992. Prediction of harvest date windows for apples. Cornell Coop. Ext. Bul. 2212:1-12.

Burkholder, C.L. and M. McCown. 1941. Effect of scoring and of a naphthyl acetic acid and amide spray upon fruit set and of the spray upon preharvest fruit drop. Proc. Amer. Soc. Hort. Sci. 38:117-120.

Byers, R.E. 2003. Flower and fruit thinning and vegetative: Fruiting balance, p. 409-436. In: Ferree, D.C. and I.J. Warrington (eds.). Apples: Botany, production and uses. CABI Publishing, Cambridge, UK.

Byers, R.E., J.A. Barden, and D.H. Carbaugh. 1990a. Thinning of spur' Delicious' apples by shade, terbecil, carbaryl, and ethephon. J. Amer. Soc. Hort. Sci. 115:9-13.

Byers, R.E., J.A. Barden, R.F. Yound, and D.H. Carbaugh. 1990b. Apple thinning by photosynthetic inhibition. J. Amer. Soc. Hort. Sci. 115: 14-19.

Craker, L.E. and F.B. Abeles. 1969. Abscission: Role of abscisic acid. Plant Physiol. 44:1144 1149 .

Crovetti, A.J. and W.E. Schafer. 1989. Considerations in the commercial development of a plant growth regulator. Acta Hort. 239:465-476.

Edgerton, L.J. 1971. Apple abscission. HortScience 6:378-382.

Gan, S. and R.M. Amasino. 1995. Inhibition of leaf senescence by autoregulated production of cytokinin. Science 270:1986-1988.

Gent, M.P.N. and R.J. McAvoy. 2000. Plant growth retardants in ornamental horticulture: A critical appraisal, p. 89-145. In: Basra, A.S. (ed.). Plant growth regulators in agriculture and horticulture: Their role and commercial uses. The Haworth Press, Inc., Binghamton, NY.

Goldthwaite, J.J. 1988. Hormones in plant senescence, p. 553-573. In: Davies, P.J. (ed.). Plant hormones and their role in plant growth and development. Kluwer Academic Publishers, Dordrecht, The Netherlands.

Gomez-Cadenas, A., J. Mehouachi, F.R. Tadeo, E. Primo-Millo, and M. Talon. 2000. Hormonal regulation of fruitlet abscission induced by carbohydrate shortage in citrus. Plant 210 : 636-643.

Greene, D.W. 1993. A review of the use of benzyladenine (BA) as a chemical thinner for apples. Acta Hort. 329:231-236.

Greene, D.W. 2002. Chemicals, timing, and environmental factors involved in thinner efficacy on apple. HortScience 37:477-481. 
Harley, C.P., H.H. Moon, and L.O. Regimbal. 1958. Evidence that post-bloom apple-thinning sprays of naphthaleneacetic acid increase blossom-bud formation. Proc. Amer. Soc. Hort. Sci. 72:52-56.

Hartmann, H.T.A.J.H. and J. Wisler. 1968. Chemical induction of fruit abscission in olive. Calif. Agr. 22:14-16.

Lakso, A.N., D.W. Greene, and J.W. Palmer. 2006. Improvements on an apple carbon balance model. Acta Hort. 707:57-61.

Lehman, L.J., C.R. Unrath, and E. Young. 1987. Chemical fruit thinning response to spur 'Delicious' apple as influenced by light intensity and soil moisture. HortScience 22:214-215.

Liu, X., D.D. Woolard, and P. Petracek. 2010. Use of plant growth regulators to reduce abscisic acid related plant leaf yellowing. US Patent Application 20100022562A1.

McArtney, S., M. White, I. Latter, and J. Campbell. 2004. Individual and combined effects of shading and thinning chemicals on abscission and dry-matter accumulation of 'Royal Gala' apple fruit. J. Hort. Sci. Biotechnol. 79:441-448.

Mutui, T.M., H. Mibus, and M. Serek. 2005. Effect of thidiazuron, ethylene, abscisic acid and dark storage on leaf yellowing and rooting of Pelargonium cuttings. J. Hort. Sci. Biotechnol. 80: 543-550.

Nooden, L.D. 1988. Abscisic acid, auxin, and other regulators of senescence, p. 329-368. In: Nooden, L.D. and A.C. Leopold (eds.). Senescence and aging in plants. Academic Press Inc., San Diego, CA.

Osbourne, D.J. 1989. Abscission. Crit. Rev. Plant Sci. 8:103-129.

Petracek, P.D., F.P. Silverman, and D.W. Greene. 2003. A history of commercial plant growth regulators in apple production. HortScience 38: 937-942.

Porter, N.G. and R.F.M. Van Steveninck. 1966. An abscission-promoting factor in Lupinus luteus. Physiol. Plant. 40:50-54.

Rademacher, W. and T. Bucci. 2002. New plant growth regulators: High risk investment? HortTechnology 12:64-67.

Schwailler, P.G. 1996. Apple thinning guide. Great Lakes Publ. Co., Sparta, MI.

Van Staden, J., E. Cook, and L.D. Nooden. 1988. Cytokinins and senescence, p. 281-328. In: Nooden, L.D. and A.C. Leopold (eds.). Senes- cence and aging in plants. Academic Press Inc., San Diego, CA.

Walsh, C.S., H.J. Swartz, and L.J. Edgerton. 1979. Ethylene evolution in apple following postbloom thinning sprays. HortScience 14:704 706.

Waterland, N.L., C.A. Campbell, J.J. Finer, and M.L. Jones. 2010. Abscisic acid application enhances drought stress tolerance in bedding plants. HortScience 45:409-413.

Wertheim, S.J. 2000. Developments in the chemical thinning of apple and pear. Plant Growth Regulat. 31:85-100.

Williams, M.W. and L.J. Edgerton. 1981. Fruit thinning of apples and pears with chemicals. USDA-SEA Agr. Info. Bul. 289.

Yuan, R. and H. Huang. 1988. Litchi fruit abscission: Its patterns, effect of shading and relation to endogenous abscisic acid. Sci. Hort. 36:281-292.

Zacarias, L. and M.S. Reid. 1990. Role of growth regulators in the senescence of Arabidopsis thaliana leaves. Physiol. Plant. 80:549-554.

Zucconi, F., R. Stosser, and M.J. Bukovac. 1969. Promotion of fruit abscission with abscisic acid. Bioscience 19:815-817. 